\title{
RUMEN CILIATE FAUNA IN THE CHAMOIS (RUPICAPRA RUPICAPRA L.)
}

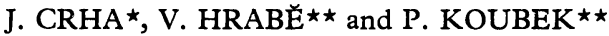 \\ $\star$ Department of Physiology, University of Veterinary Science, 61242 Brno \\ $\star \star$ Vertebrate Research Institute, Czechoslovak Academy of Sciences, 60365 Brno
}

Received Fuly 25, 1984

\begin{abstract}
Crha J., V. Hrabě, P. Koubek: Rumen Ciliate Fauna in the Chamois (Rupicapra rupicapra L.). Acta vet. Brno, 54, 1985: 141-147.

Total numbers, generic distribution and percentage species distribution were determined for the ciliate protozoa in rumen fluid obtained frcm the chamois $(R u p i-$ capra rupicapra L.). Ten individuals shot in the Jeseníky Mountains in November and December were used in the study. A total of $792000 \pm 115031$ ciliates were found per $1,0 \mathrm{ml}$ of rumen fluid. Thirteen ciliate species were identified as follows: Entodinium cervi, Ent. dubardi, Ent. exiguum, Ent. laeve, Ent. loboso-spinosum, Ent. nanellum, Ent. parvum, Ent. rupicaprae, Ent. simplex, Diplodinium costatum, Eremoplastron impalae, Eudiplodinium maggii and Epidinium ecaudatum.
\end{abstract}

Ciliata, Entodiniomorphida, rumen, wild ruminants.

Rumen ciliates of chamois were first studied by Wertheim (1934) in three animals shot in Slovenian mountains, and by Christl (1955) in five individuals from Bavarian mountains. Except for the autochthonous chamois residing in the High Tatra mountains (Blahout 1972) all chamois populations living in other regions of Czechoslovakia had been introduced.

The aim of the present study was to compare the ciliate fauna of the rumen of alpine chamois with that of the individuals of the introduced chamois population residing in the Jeseníky mountains.

\section{Materials and Methods}

Ciliate fauna of the rumen of 10 chamois was examined. The animals were shot in the Jeseníky mountains in November and December 1982 (8 individuals - 6 males, among them one kid and 2 females), and in the same months of 1983 ( 2 individuals - 1 male and 1 female).

After sampling, the rumen fluid was mixed with equal amount of $10 \%$ formalin. Total numbers of ciliates and their generic distribution were determined in $1,0 \mathrm{ml}$ rumen fluid using the Fuchs Rosenthal chamber. The individual ciliate species were determined both directly in a $5 \%$ preservative formalin solution and after staining the nucleus (with acid carmine, Garazzi's glycerin hematoxylin, Heidenheim ferrous hematoxylin, methyl green). The skeletal plates were stained with chlorzincjodide and differentiated with concentrated sulphuric acid. Specimens of the individual ciliate species were measured. Their identification was based on the descriptions of Dogiel 1927), Kofoid and MacLennan (1930-33), Wertheim (1935), Lubinsky (1957) and Latteur (1966).

\section{Results}

A total of $792000 \pm 115031$ ciliates were found per $1,0 \mathrm{ml}$ rumen fluid of chamois. Of this number, the genus Entodinium comprised $744800 \pm 106800$, Diplodinium $15800 \pm 3300$, Eremoplastron $18700 \pm 7300$, Eudiplodinium $4300 \pm 1100$, and Epidinium $14400 \pm 7700$ ciliates. Total numbers of ciliates are given in Table 1. 
Table 1

Ciliate numbers in thousands per $1 \mathrm{ml}$ of the rumen fluid in chamois

\begin{tabular}{|c|c|c|c|c|c|c|}
\hline Genus & Host No. & $1.0 َ$ & $2 .+9$ & 3. 9 & $4.3^{\pi}$ & $5.0^{\pi}$ \\
\hline \multicolumn{2}{|c|}{$\begin{array}{l}\text { Entodinium } \\
\text { Diplodinium } \\
\text { Eremoplastron } \\
\text { Eudiplodimium } \\
\text { Epidinium }\end{array}$} & $\begin{array}{r}737 \pm 75.14 \\
17 \pm 4.43 \\
14 \pm 1.15 \\
11 \pm 1.91 \\
3 \pm 1.00\end{array}$ & $\begin{array}{r}832 \pm 44.57 \\
22 \pm \quad 6.00 \\
0 \pm 0.00 \\
2 \pm 1.15 \\
0 \pm 0.00\end{array}$ & $\begin{array}{r}625 \pm 43.33 \\
10 \pm 1.15 \\
6 \pm 1.15 \\
4 \pm 1.41 \\
0 \pm 0.00\end{array}$ & $\begin{array}{r}218 \pm 16.85 \\
6 \pm 2.58 \\
5 \pm 3.78 \\
2 \pm 1.15 \\
67 \pm 16.36\end{array}$ & $\begin{array}{r}1252 \pm 70.89 \\
39 \pm 3.85 \\
5 \pm 1.91 \\
5 \pm 1.91 \\
50 \pm 3.82\end{array}$ \\
\hline \multicolumn{2}{|c|}{ Total } & $782 \pm 72.56$ & $856 \pm 33.62$ & $645 \pm 45.93$ & $238 \pm 19.32$ & $1351 \pm 70.10$ \\
\hline Genus & Host No. & 6.0 & 7. $0^{\star}$ juv. & 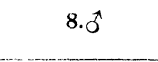 & 9.9 & $10 . \sigma^{\pi}$ \\
\hline \multicolumn{2}{|c|}{$\begin{array}{l}\text { Entodinium } \\
\text { Diplodinium } \\
\text { Eremoplastron } \\
\text { Eudiplodinium } \\
\text { Epidinium }\end{array}$} & $\begin{array}{r}715 \pm 32.75 \\
12 \pm \quad 4.89 \\
1 \pm 1.00 \\
0 \pm 0.00 \\
0 \pm 0.00\end{array}$ & $\begin{array}{r}1255 \pm 49.24 \\
25 \pm 7.72 \\
43 \pm 2.51 \\
4 \pm 0.00 \\
1 \pm 1.00\end{array}$ & $\begin{array}{r}919 \pm 18.28 \\
7 \pm 1.91 \\
71 \pm 2.51 \\
9 \pm 4.12 \\
23 \pm 5.74\end{array}$ & $\begin{array}{r}419 \pm 3.41 \\
5 \pm 1.91 \\
9 \pm 2.51 \\
6 \pm 2.58 \\
0 \pm 0.00\end{array}$ & 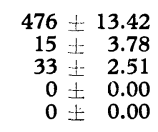 \\
\hline \multicolumn{2}{|c|}{ Total } & $728 \pm 34.94$ & $1328 \pm 47.71$ & $1029 \pm 23.00$ & $439 \pm 4.12$ & $524 \pm 15.66$ \\
\hline
\end{tabular}

Thirteen ciliate species were identified, nine of the genus Entodinium, and one of each of the genera Diplodinium, Eremoplastron, Eudiplodinium and Epidinium (Fig. 1).

The following species were found:

Order: Entodiniomorphida REICHENOW, 1929

Family: Ophryoscolecidae STEIN, 1858

Genus: Entodinium STEIN, 1858

1. Entodinium cervi KUBfKOVÁ, 1935

Species with one caudal projection was first described in deer by Kubíková (1935). Sládeček (1947) found this species in deer and fallow deer and designated it Entodinium dubardi forma cervi, Crha (1972) detected the same species in fallow deer. In present material the size of specimens was smaller than that given by other authors in other ruminant species.

Body length (1) $51 \mu \mathrm{m}(42-60 \mu \mathrm{m})$, body width (w) $33 \mu \mathrm{m}(24-42 \mu \mathrm{m})$, lenght to width ratio 1.5 .

Occurrence in $40 \%$ of examined hosts.

\section{Entodinium dubardi BUISSON, 1923}

The body is wider (length to width ratio 1.5) than in similar species Entodinium simplex (1:w ratio 1.7). This species - Entodinium dubardi was first described by Buisson (1923) in roe deer rumen, later it was found by Sládeček (1947) and Blancou et. al. (1984) in the same host animal. It was also found in African antelopes by Dogiel (1925) and Noirot - Timothée (1959). It was further observed in . rumen contents of deer (Wertheim 1935; Dogiel 1927; Sládeček 1947; Zielyk 1961), in fallow deer (Sládeček 1947; Crha 1972), in reindeer (Lubinsky 1958), in moose (Dogiel 1934; Dehority 1974), in musk-ox (Dehority 1974), and in seraw (Imai et al. 1981). In chamois it was observed by Wertheim (1934), Christl (1955) and Blancou et al. (1984).

Body length: $37 \mu \mathrm{m}(30-54 \mu \mathrm{m})$, body width: $24 \mu \mathrm{m}(18-30 \mu \mathrm{m})$, length to width ratio 1.5 .

Occurrence in $100 \%$ of examined hosts. 


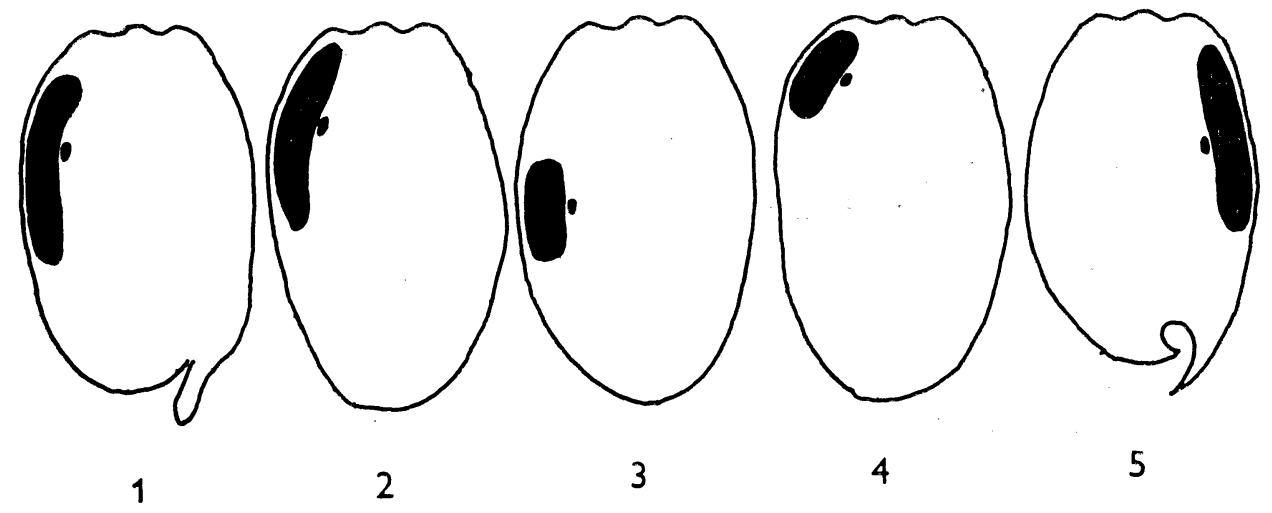

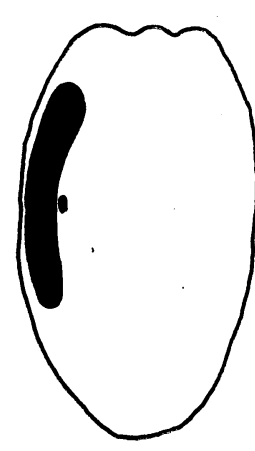

6

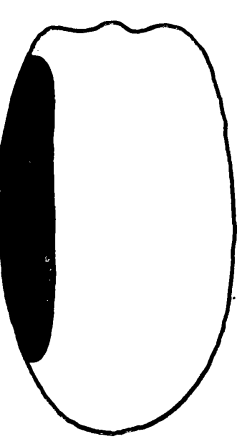

7

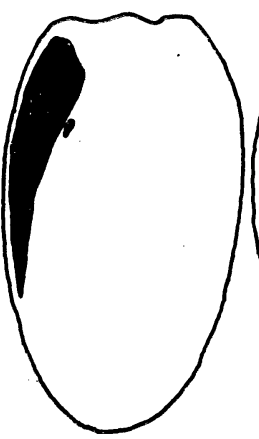

8

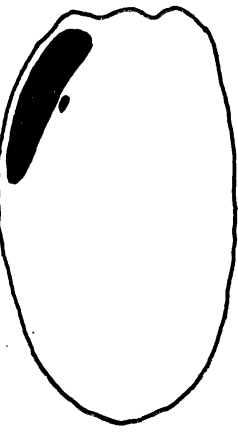

9

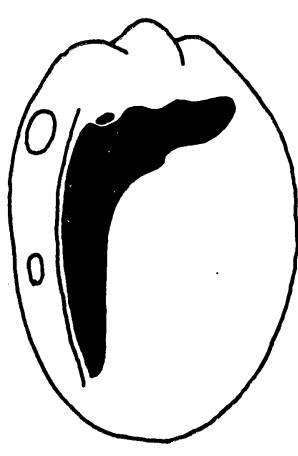

10

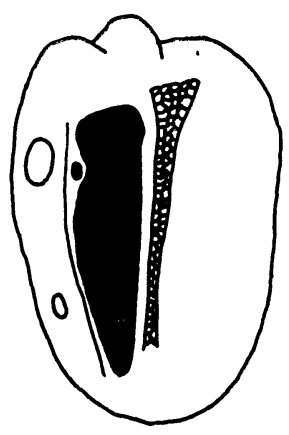

11

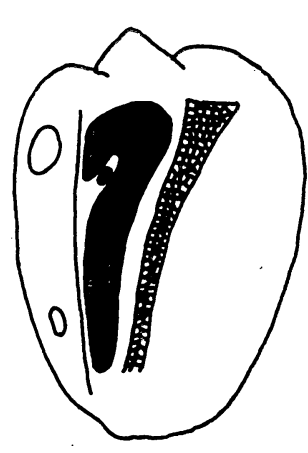

12

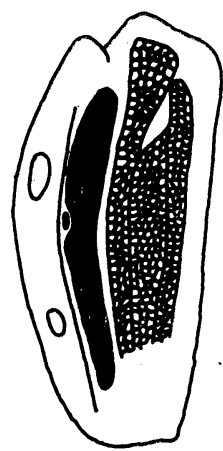

13

Fig. 1

1 - Entodinium cervi, 2 - Ent. dubardi, 3 - Ent. exiguum, 4 - Ent. laeve, 5 - Ent. loboso-spinosum, 6 - Ent. nanellum, 7 - Ent. parvum, 8 - Ent. rupicaprae, 9 - Ent. simplex, 10 Diplodinium costatum, 11 - Eremoplastron impalae, 12 - Eudiplodinium magii, 13 - Epidinium ecuadatum. 


\section{Entodinium exiguum DOGIEL, 1925}

One of the smallest species among the rumen ciliates found in reindeer (Dogiel 1925; Lubinsky 1958), deer (Wertheim 1934; Sládeček 1947), fallow deer (Sládeček 1947; Crha 1972), in African antelopes (Noirot - Timothée 1959) and in giraffes (Noirot - Timothée 1963).

Body length: $24 \mu \mathrm{m}(18-30 \mu \mathrm{m})$, body width: $15 \mu \mathrm{m}(12-18 \mu \mathrm{m})$, length to width ratio 1.6 .

Occurrence in $100 \%$ of examined hosts.

\section{Entodinium laeve DOGIEL, 1925}

The species Entodinium anteronucleatum was first described from the rumen contents of reindeer by Dogiel (1925) in three forms: laeve, monolobum and dilobum. Lubinsky (1958) found predominating laeve form in reindeer. Das - Gupta (1935) detected this species in the goat. In our material the size of this species was smaller than in other studies.

Body length: $39 \mu \mathrm{m}(30-48 \mu \mathrm{m})$, body width: $25 \mu \mathrm{m}(21-30 \mu \mathrm{m})$, length to width ratio 1.6 .

Occurrence in $80 \%$ of examined hosts.

\section{Entodinium loboso-spinosum DOGIEL, 1925}

The species encountered in cattle, sheep and goats (Dogiel 1927; Hsiung 1931; Das - Gupta 1935; Crha 1969; Vasily and Mitchel 1972 and others), as well as in wild ruminants (Dogiel 1927; Wertheim 1934; Sládeček 1947; Crha 1972; Imai et al. 1981; Blancou et al. 1984).

Body length: $51 \mu \mathrm{m}(42-60 \mu \mathrm{m})$, body width: $39 \mu \mathrm{m}(30-48 \mu \mathrm{m})$, length to width ratio 1.3 .

Occurrence in $10 \%$ of examined hosts.

\section{Entodinium nanellum DOGIEL, 1921}

One of the smallest rumen ciliate species encountered both in domesticated and wild ruminants. It was detected in the chamois by Wertheim (1934), Christl (1955) and Blancou et al. (1984). In the japanese seraw it was observed by I mai et al. (1981) as one of the most abundant species.

Body length: $21 \mu \mathrm{m}(18-24 \mu \mathrm{m})$, body width: $15 \mu \mathrm{m}(12-18 \mu \mathrm{m})$ length to width ratio 1.7 .

Occurrence in $90 \%$ of examined hosts.

\section{Entodinium parvum BUISSON, 1923}

The species was described by Buisson (1923) in African antelopes, later confirmed by Noirot - Timothée (1959). In the chamois it was encountered by Christl (1955) and Blancou et al. (1984).

Body length: $47 \mu \mathrm{m}(36-54 \mu \mathrm{m})$, body width: $27 \mu \mathrm{m}(18-36 \mu \mathrm{m})$, body length to width ratio 1.7 .

Occurrence in $40 \%$ of examined hosts.

\section{Entodinium rupicaprae CHRISTL, 1955}

The species first described in the chamois from Bavarian mountains by Christl (1955). Macronucleus much narrower at its posterior end, extending through $2 / 3$ of the body.

Body length: $36 \mu \mathrm{m}(30-42-\mu \mathrm{m})$, body width: $21 \mu \mathrm{m}(18-24 \mu \mathrm{m})$, length to width ratio 1.7 .

Occurrence in $60 \%$ of examined hosts. 


\section{Entodinium simplex DOGIEL, 1925}

Common species in nearly all ruminants, both domesticated and wild. In the chamois found by Wertheim (1934), Christl (1955) and Blancou et. al. (1984). I mai et al. (1981) describe this species to be the most abundant in japanese seraw. Body length: $42 \mu \mathrm{m}(30-54 \mu \mathrm{m})$, body width: $24 \mu \mathrm{m}(18-31 \mu \mathrm{m})$, length to width ratio 1.7.

Occurrence in $100 \%$ of examined hosts.

Genus: Diplodinium SCHUBERG, 1888

10. Diplodinium costatum DOGIEL, 1925

Species similar to Diplodinium rangiferi, first described by Dogiel (1925) in African antelopes, be Wertheim (1934) and by Christl (1955) in the chamois.

Body length: $105 \mu \mathrm{m}(78-132 \mu \mathrm{m})$, body width: $72 \mu \mathrm{m}(60-84 \mu \mathrm{m})$, length to width ratio 1. 4.

Occurrence in $100 \%$ of examined hosts.

Genus: Eremoplastron KOFOID et Mac LENNAN, 1932

11. Eremoplastron impalae (DOGIEL), 1925

In contrast to the species Eremoplastron bovis with micronucleus situated in vicinity of the macronucleus, in this species the micronucleus is near the anterior end of macronucleus. Dogiel designated this species Eudiplodinium neglectum forma impalae and he found it in antelopes and in the reindeer. Also Lubinsky (1958) found E. impalae in reindeer.

Body length: $81 \mu \mathrm{m}(54-108 \mu \mathrm{m})$, body width: $54 \mu \mathrm{m}(36-72 \mu \mathrm{m})$, length to width ratio 1.5 .

Occurrence in $90 \%$ of examined hosts.

Genus: Eudiplodinium DOGIEL, 1927

12. Eudiplodinium magii FIORENTINI, 1889

Large size species with typical hook-shaped macronucleus very common in nearly all domesticated and wild ruminants. Christl (1955) did not found this species in chamois but the described a similar new species Eudiplodinium maggioides. Comparing their morphological signs seems to indicate, however, possible identity of the two species.

Body length: $129 \mu \mathrm{m}(78-180 \mu \mathrm{m})$, body width: $81 \mu \mathrm{m}(54-108 \mu \mathrm{m})$ length to width ratio 1.5 .

Occurrence in $80 \%$ of examined hosts.

Genus: Epidinium CRAWLEY, 1923

13. Epidinium ecaudatum FIORENTINI, 1889

Species without caudal projection, common in nearly all domesticated and wild ruminants.

Body length: $126 \mu \mathrm{m}(84-168 \mu \mathrm{m})$, body width: $54 \mu \mathrm{m}(36-72 \mu \mathrm{m})$, length to width ratio 2.3.

Occurrence in $60 \%$ of examined hosts.

\section{Discussion}

In chamois from the Slovenian mountains 8 rumen ciliate species were found (Wertheim 1934), in those form the Bavarian mountains 18 species have been described by Christl (1955). The author explained this considerable variety of 
ciliate species by common roaming areas of the chamois and other ruminants, especially the deer. Among 13 species identified in our material only 3 ciliate species (Entodinium nanellum, Ent. simplex and Diplodinium costatum) are the same as found by the above-mentioned authors. Our finding of further 6 species (Entodinium dubardi, Ent. exiguum, Ent. parvum, Ent. rupicxprae, Eudiplodinium maggii, and Epidinium ecaudatum) corresponds to that of Christl (1955). Four species (Entodinium cervi, Ent. laeve, Ent. lobosospinosum and Eremoplastron impalae) found in our material have not been reported by these authors, and, on the other hand, the representative of the genus Ophryoscolex found by both writers was not detected in our study.

Microfauna of the rumen of chamois from the French mountains (Jura) comprised 14 species of ciliates, of which 7 were the same as in specimens of Christl (1955) and in our material. In Japanese seraw (Capricornis crispus TEMMINCK, 1854) from subfamily Rupicaprinae, the rumen microfauna contained 11 ciliate species (I mai et al. 1981) among which 5 species were also found in our group of chamois, and in experimental material of other European writers. Neither the species $\mathrm{Da}$ sytricha ruminantium found in Japanese seraw nor other holotrichs were detected in the European chamois, and it was not found in our specimens.

\section{Bachoroví nálevníci kamzíka horského (Rupicapra rupicapra L.)}

Byla vyšetřena mikrofauna bachoru kamzíka horského (Rupicapra rupicapra L.) $\mathrm{z}$ deseti zviŕat ulovených $\mathrm{v}$ horách Jeseníky. $\mathrm{V} 1,0 \mathrm{ml}$ bachorové tekutiny bylo zjištěno celkem $792000 \pm 115031$ nálevníkủ. Bylo nalezeno celkem 13 druhủ nálevníků: Entodinium cervi, Ent. dubardi, Ent. exiguum, Ent. laeve, Ent. loboso-spinosum, Ent. nanellum, Ent. parvum, Ent. rupicaprae, Ent. simplex, Diplodinium costatum, Eremoplastron impalae, Eudiplodinium maggii a Epidinium ecadatum.

\section{Инфузории в рубце серны (Rupicapra rupicapra L.)}

Проводили анализ представителей инфузорий в рубце серны (Rupicapra rupicapra L.). Анализ проводили у десяти животных, пойманных в горах Йесеники в ноябре и декабре месяце. В 1,0 мл жидкости первого желудка было обнаружено $792000 \pm 115031$ инфузорий. Было идентифицировано 13 видов инфузорий, а именно: Entodinium cervi, Ent. dubardi, Ent. exiguum, Ent. laeve, Ent. loboso-spinosum, Ent. nanellum, Ent. parvum, Ent. rupicaprae, Ent. sipmlex, Diplodinium costatum, Eremoplastron impalae, Eudiplodinium maggii, Epidinium ecaudatum.

\section{References}

BLAHOUT, M.: Zur Taxonomie der Population von Rupicapra rupicapra (Linné, 1758) in der Hohen Tatra. Zool. listy 21, 1972: 115-132.

BLANCOU, J. - BONHOMME, A. - BARRAT, J. - PONS, N.: Microfaune du rumen des herbivores sauvages. Étude préliminaire sur le chevreuil et le chamois. Revue Méd. Vét., 135, 1984: $141-148$.

BUISSON, J.: Sur quelque Infusoires nouveaux ou peu connus parasites des Mammiferes. Ann.

Parasitol. 1, 1923: 209-246.

CHRISTL, H.: Beiträge zur Kenntnis der Panseninfusorien einheimischer Wiedekäuer. I. Gemse

(Rupicapra rupicapra L.). Z. Parasitenkunde, 17, 1955: 185-192.

CRHA, J.: Infusoria of the Rumen of Fattened Cows. Acta vet. Brno, 38, 1969: 491-495. 
CRHA, J.: Rumen Ciliates in Fallow Deer (Dama dama L.) in Náměšt Preserve. Acta vet. Brno, 41, 1972: $355-362$.

DAS-GUPTA, M.: Preliminary observations on the Protozoan fauna of the rumen of the India goat, Capra hircus Linn. Arch. Protistenk., 85, 1935: 153-172.

DEHORITY, A. B.: Rumen Ciliate Fauna of Alaskan Moose (Alces americana), Musk-Ox (Ovibos moschatus) and Dall Mountain Sheep (Ovis dalli). J. Protozool., 21, 1974: 26-32

DOGEL, V. A.: Novyje parazitičeskije infusoriji iz želuadka severnovo olenja. Rus. Arch. Frotist., 4, 1925: $43-65$.

DOGIEL, V.: Nouveaux Infusoires de la famille des Ophryoscolécides parasites d'Antilopes africaines. Ann. Parasitol. 3, 1925: 116-142.

DOGIEL, V.: Monographie der Familie Ophryoscolecidae. Arch. Protistenk., 59, 1926: 1-288.

DOGIEL, V.: Angaben über die Ophryoscolecidae des Wildschafes aus Kamtschatka, des Elches und des Yaks, nebst deren zoogeographischen Verwertung. Arch. Protistenk, 82, 1934: 290-297.

HSIUNG, T. S.: The protozoan fauna of the rumen of the chinese sheep. Bull. Fan. Mem. Inst. Biol., 2, 1931: 29-43.

IMAI, S. - ABE, M. - OGIMOTO, K.: Ciliate Protozoa from the Rumen of the Japanese Serow, Capricornis crispus (Temminck), Jpn. J. Vet. Sci., 43, 1981: 359-367.

KOFOID, C. A. - MAC LENNAN, R. F.: Ciliates from Bos indicus L. Univ. Calif. Publ. Zool., 33, 1930: 471-544, 37, 1932: 53-152, 39, 1933: 1-34.

KUUBÍKOVÁ, M.: Infusorien aus dem Pansen von Cervus elaphus L. Zool. Anz., 111, 1935: $175-177$.

LATTEUR, B.: Contribution a la systematique de la famille des Ophryoscolecidae Stein. Ann. Soc. R. Zool. Belg., 96, 1966: 117-144.

LUBINSKY, G.: Studies on the evolution of the Ophryoscolecidae (Ciliata: Oligotricha) III. Phylogeny of the Ophryoscolecidae based on their comparative morphology. Can. J. Zool., 35, 1957: $141-159$.

LUBINSKY, G.: Ophryoscolecidae (Ciliata: Entodiniomorphida) of Reindeer (Rangifer tarandus L.) from the canadian arctic. Can. J. Zool., 36, 1958: 819-835.

NOIROT-TIMOTHÉE, C.: Diplodinium moucheti n. sp. (Infusoire Cilié). Remarques sur l'evolution des Ophryoscolecidae en Afrique. Ann. Sci. Nat., Zool., 1, 1959: 331 - 337.

NOIROT-TIMOTHÉE, C.: Sur les Ciliés du rumen de Giraffa camelopardalis L., C. R. Acad. Sci., 256, 1963: 5400-5401.

SLÁDEČEK, F.: Ophryoscolecidae z bachoru jelena (Cervus elaphus L.), daňka (Dama dama L.) a srnce (Capreolus capreolus L.). Věstník Čsl. zool. spol., 10, 1946: 201-231.

VASILY, D. B. - MITCHEL, J. B.: The identification of rumen ciliates from eastern Bos taurus. Trans. Amer. Micros. Soc., 93', 1974: 248-253.

WERTHEIM, P.: Les Infusoires de l'estomac de Rupicapra rupicapra L. Ann. Parasitol., 12, 1934: 390-393.

WERTHEIM, P.: Infusorien aus dem Wiederkäuermagen von gebiete Jugoslawiens nebst einer Übersicht dieser Tierchen von Balkanhalbinsel-Bereich und ein kurzer Bericht über die Pferdedarminfusorien, zugleich Revision der Familie Ophryoscolecidae. Vet. Arh., 5, 1935: 388-536.

WERTHEIM, P.: Über die Infusorienfauna aus dem Magen von Cervus elaphus L. Z. Parasitenkunde, 7', 1935: 395-400.

ZIELYK, M. W.: Ophryoscolecid Fauna from the Stomach of the White-tailed Deer (Odocoileus virginianus borealis), and Observations on the Division of Entodinium dubardi Buisson 1923 (Ciliata Entodiniomorpha), J. Protozool., 8, 1961: 33-41. 